\title{
Higher Education Excellence and Local Economic Development: The Case of the Entrepreneurial University of Twente
}

\author{
LUCIANA LAZZERETTI \& ERNESTO TAVOLETTI
}

Dipartimento di Scienze Aziendali, Facoltà di Economia, Università di Firenze, Via delle Pandette 6, 50123 Firenze, Italy

\begin{abstract}
By tradition or intellectual necessity, universities pursue a main objective: increasing and transferring knowledge that is internationally relevant for the whole of mankind. But new powerful socio-economic forces are demanding universities to be engaged in regional economic development and their knowledge to be relevant in terms of local employment, university spin-offs and growth. These two objectives are traditionally considered as not complementary or even mutually exclusive. Through a case study regarding the Dutch University of Twente, this article shows that local economic relevance and international excellence are not incompatible objectives: they were not at the University of Twente; they can be reached even in a new born and poor endowed university, located in a peripheral, depressed and not industrialized countryside. This article argues that a strong entrepreneurial vision and the adoption of a different concept of knowledge may be the key for other small and peripheral European universities, in order to reach both local economic relevance and international excellence. The article will contribute and enrich the regional studies debate, introducing to it some higher education policy issues and ideas.
\end{abstract}

\section{Introduction ${ }^{1}$}

In the past, state employment was the main single outlet for graduates and there was a strong link between qualifications and occupations. The increased number of graduates, the currently mass status of higher education and the need to provide skills to a high technology-based economy (Cooke, 2003), compelled universities to deal with the problem of satisfying the overriding demands of the private sector, the only available outlet for most of the graduates.

Correspondence Address: Luciana Lazzeretti, Dipartimento di Scienze Aziendali, Facoltà di Economia, Università di Firenze, Via delle Pandette 6, 50123 Firenze, Italy. Tel.: (39) 55-4374698; Fax (39) 55-4374911; Email: luciana.lazzeretti@unifi.it 
Mass higher education and the 'tyranny of numbers' (Wolf, 2002, p. 168) produced a strong deterioration in the conditions under which students worked and studied and a strong need to reduce public expenditure. Staff/student ratios, student debt and every possible indicator testify this deterioration of the quality of services provided by universities (OECD, 2002).

This glaring contradiction between decreasing effective quality of mass higher education and increasing rhetoric about the so called knowledge economy is made worse by the unemployment that is increasing among even the holders of the best diplomas (Wolf, 2002). In some European regions the level of unemployment among highly educated people is astonishingly high and in central Italy the level of unemployment amongst young people with primary or no schooling is practically the same as amongst individuals with university degrees: $14.1 \%$ and $14.5 \%$ respectively (ISTAT, 2001).

Because of the mass higher education phenomenon, university funding has constantly increased in the last decades, but it is almost entirely domestic, and in most countries (including the US) primarily governmental. Politicians and public opinion demand that the benefits of university research and education are effectively, if not primarily, captured by domestic workers and investors, in terms of both employment and growth. In Europe an increasing proportion of funding comes from regional and local government so that public demands are increasingly focused on the regional and local level. The demands are increasing because of the wide spread belief that higher education is the key to reach modern economic development. Alison Wolf's statement: "the belief in education for growth runs deep and wide beyond our political classes, replacing socialism as the great secular faith of our age" (Wolf, 2002, p. 10) is probably more than a provocation.

On the other side universities are, by tradition or by intellectual necessity, open to scholars from any country, in order to pursue the main objective of increasing and transferring knowledge that is relevant for the whole of mankind. This is why a strategy, which focuses on regional economic development and is entirely accountable to domestic and local funding, might not be compatible with university tradition and universal mission of international excellence.

This paper argues that the University of Twente in the Netherlands tackled this dilemma effectively and managed to turn problems into opportunities. In particular, it managed to satisfy its major stakeholders' needs and expectations: students, academic personnel, the region of Twente and its economy. In fact, as far as the regional economy is concerned, it will be shown that the University Twente gave an important contribution to its development and revitalization, in terms of employment, spin-offs and growth. At the same time the University of Twente is a widely recognized centre of excellence in fields such as membrane science and technology, biomedical materials and technologies, nanotechnology and information and communication technology (ICT).

There have been many management fads (Birnbaum, 2001) in higher education, such as 'programme planning budgeting system', 'management by objectives', 'zero-base budgeting', 'strategic planning', 'benchmarking' and more recently 'total quality management' and 'business process reengineering'. However, as pointed out by Robert Birnbaum, none of these management practices proved very effective by themselves in higher education, because "we know from experience that it is no easier to get people to implement a management strategy inconsistent with their values than it is to get internal combustion from water" (Birnbaum, 2001, p. 12); if this statement may be debatable for firms, it is not for 'heavy bottom' institutions such as universities. As is going to be shown, 
Twente's success comes from its ability to change organizational culture and internal values through the ideologization of the entrepreneurial university idea. As a consequence of this change some of the most popular management practices, such as 'lup-sum budgeting', were effective in Twente.

University of Twente was involved in the production of a kind of knowledge "as ability to produce an effective action in a consensual domain" that is defined as "social knowledge' in previous work (Tavoletti, 2004) and it is argued that it plays an important role in explaining its success as entrepreneurship did.

The case of the University of Twente does not provide a 'ready-made recipe', because there is not such a thing as a 'ready-made recipe' in the management of higher education institutions. It shows that, if a strong entrepreneurial vision and a proper concept of knowledge are provided:

(a) local economic relevance for universities, in terms of both employment and growth, and their international excellence are not incompatible objectives because they were not in Twente;

(b) the two objectives can be reached even in a new born and poor endowed university, located in a peripheral, depressed and not industrialized countryside, so that, if not a model of development is provided, a successful example for 'inspiration' to peripheral universities so numerous in Europe is.

In so doing the article will introduce in the current regional studies debate models and ideas that are typical of higher education policy studies.

\section{Methodology and Data Sources}

The methodology used is the case study methodology as defined by Robert Yin (1989) and the unit of analysis is basically the Dutch University of Twente even if attention is paid to the region where the University is embedded.

Multiple sources of evidence were used: direct observation by making field visits to the case study 'site'; some interviews of an open-ended nature (Yin, 1989, p. 89) to students, administrative personnel and academic personnel; documentation, especially in the form of studies and evaluations regarding the University of Twente itself, from different disciplinary perspectives and with a dominance of higher education policy studies.

Interviews and direct observation were critical to understand which were the most important factors and episodes that should be focused on, in order to explain the University of Twente phenomenon, but documentation was the hugest source of data.

The documentation is entirely listed in the references but two of them had a major role: Karnbeek (2001) as a valuable source of data for university spin-offs, and to assess the University of Twente general economic impact, and Curie et al. (2003) as a source of already published interviews across different universities about relevant issues.

The University of Twente was visited twice: 10 days in March 2003 and 10 days in July 2004. The first field visit was an exploratory one, in order to collect documents, go through the literature available on site, visit the University and its facilities and conduct openended interviews with students, senior academics and senior administrative personnel. The second visit was in order to present an early draft of this article to a distinguished and international community of researchers in higher education research policy, from 
the local Centre for Higher Education Policy Studies (CHEPS) and from different nations, in order to receive comments and suggestions. During the second field visit, a limited number of open-ended interviews were conducted with academics and students.

The interviews were conducted both during the two field visits at the University of Twente, in March 2003 and July 2004, and at the University Maribor, Slovenia, in July 2003, where many academics and students from the University of Twente were met. The following 15 people from the University of Twente were interviewd: the director of the "Dutch Institute for Intensive Entrepreneurship (NIKOS)", the director of the "Centre for Higher Education Policy Studies (CHEPS)', the director of the "Centre for Studies of Science Technology and Society", the director of the University of Twente incubator 'Business and Technology Centre (BTC)', the director of the 'European Universities Association (EUA)' (giving a total of five senior male administrative personnel, three of them also senior academics at the University of Twente); two senior male academics; three junior male academics; five Ph.D. students.

\section{Twente's View}

In 2003, Jan Curie, Richard De Angelis, Harry De Boer, Jeroen Huisman and Claude Lacotte, produced a detailed cross-case study and a comparison among the University of Avignon (France), the University of Twente (Netherlands), the University of Oslo (Norway) and the Boston College (USA), and contrasted the results with Australia as an archetype of an Anglo-American country. They conducted a qualitative study, based on 131 interviews with a small number of senior administrators and an approximately equal number of academic staff from professional schools (education, applied languages, law), sciences and social sciences. The sample included 37 individuals from Boston, 32 from Avignon, 31 from Oslo, and 31 from Twente. The measures of economic and social levels of the five countries are very similar: high-income, high standard of living, industrialized nations with mid to high gross domestic product (GDP) per capita.

The interviews investigated issues currently debated in higher education such us privatization, competition, entrepreneurialism, university governance, accountability, employment flexibility and new technologies. These interviews reveal that the University of Twente is the only one in where practices and attitudes are favourable to significant private sector and competitive reforms. In other universities such changes are partial, pragmatic, and subject to immediate modifications if they fail to work. Even in the private, non-profit American Jesuit Boston College, there is support for many practices that are not inspired by private, corporate or capitalist models, such as widespread tenure, academic autonomy and freedom, widespread consultation, support for academic fields by criteria of academic excellence and freedom.

In Avignon and Oslo the language is "central authorities have cut existing budgets". In Boston and Twente it is "management requested to seek more funds from outside sources": in Twente $97 \%$ of the interviewees said that the management did; in the Boston College this percentage is $76 \%$.

It is interesting to underline that in its mission statement Twente describes itself as "an entrepreneurial university for academic education and research, offering training courses in both technical and social disciplines" (Clark, 1998, p. 51). It combines technological and social sciences and its main focus concerns excellent research and labour market needs, ensuring that graduates have little difficulties finding employment. 
Twente's idea of being an 'entrepreneurial university' dates back to the early 1980s, when it decided to establish close links with regional industries and to follow its aspiration to be leader in ICT. Since the early 1980s, concerning research competition, Twente has adopted practices that are very similar to those adopted within Anglo-American universities and absolutely different from the European ones. According to a senior Twente's academic in social sciences, very representative of the general view "we are already considered the most entrepreneurial university in the Netherlands [...]. We have to find money from the market. We do it well both in social sciences and in engineering. There is a lot of contract research and setting up of companies. There is even the idea of making students become young entrepreneurs as well" (Currie et al., 2003, p. 64). At Twente, many people emphasize that contacts with industry satisfy students' desire to work at thing that are real and provide greater academic freedom: "the advantage is gaining greater academic freedom. If we can get funds outside of government funding, it gives us more financial autonomy" (Currie et al., 2003, p. 68).

What is needed to be stressed here is that the University of Twente's point of view, regarding entrepreneurship, creates a strong and vital connection with local actors and helps the institution to produce a kind of knowledge that is the result of actions and interactions with the social and economic community in which the institution is embedded. In fact, it is possible to argue that the objective of producing knowledge as "ability to produce an effective action in a consensual domain" may be the best way, for higher education institutions, in order to deal with the problem of intellectual unemployment and in order to provide a career to their students (Tavoletti, 2004).

Twente's view about accountability, as 'answerability for performance' (Romzek, 2000 , p. 22) or "obligation to report to others, to explain, to justify, to answer questions about how resources have been used and to what effect" (Trow, 1996, p. 310), is interesting as well.

In 1985 the Netherlands decided to shift from a rather dominant system of state control to a system of state supervision. The white paper Higher Education Autonomy and Quality (HOAK) stated the government's view on higher education for the following years. The major point was the shifting from ex ante measures, controlling quality and setting the rules and procedures in detail, to ex post evaluations of quality, making the institutions themselves primarily responsible for maintaining the quality of education.

In the Netherlands the University of Twente was among the first ones to respond actively to this change in government's strategy and four different methods for monitoring performance of academics were established: annual individual reviews without sanctions, teaching surveys, reports from the department chair, annual reviews with bonuses and task reassignments. What is special about Twente and makes it different from many other institutions is that most of the academics appreciated the monitoring system and considered it effective. Over half of the responses (54\%) indicated, in fact, that the measures were effective (Currie et al., 2003, p. 134). This declaration shows the majority belief: "Yes, I think they do have positive influences in the long run. I've been working at the university for 20 years, and in the beginning there were few monitoring activities in research or in teaching. And now I would say that these monitoring activities have improved the quality of teaching and research" (Currie et al., 2003, p. 134).

As far as academic employment is concerned, Twente and the Dutch system in general have moved toward a much greater flexibility than other European countries, except the UK academic personnel seem to accept these changes and are not concerned about 
academic freedom, probably because of the traditional Dutch tolerance of diversity and freedom of speech: "our status of workers in this university will be more like [in] companies. There are quite a few restrictions on being fired. Even in the private sector it is not too easy to get rid of personnel, but they can. The differences between public and the private sector employees are diminishing. So the civil servant rules are systematically changing in the direction of private companies, and that's a national policy. And the system of companies is to have some sort of open-ended contract where you can be fired if there are financial problems or the factory is closing down. There is a series of steps to be taken, but once these are guaranteed than that should serve for all employees, whether private or public (Twente, Senior, Male, Manager)" (Currie et al., 2003, pp. 140-141).

The appearance is that Twente and the Dutch system in general have maintained the legal status of civil servants for academic staff, like in France, Italy, Spain or Norway. Nevertheless, even if the government did not abolish the public character of higher education and transform universities into completely private enterprises, according to de Weerte and Van Vucht Tijsen (1999) the devolution of responsibilities for salary negotiations to institutions is a strong shift from the 'public service relationship', typical of European countries, to the 'contractual one', typical of Anglo-Saxon countries, where higher education institutions are not formally part of the state and have an autonomous status.

The University of Twente has the highest percentage of responses against tenure or permanency ('No'): it's 32\% in Twente, 5\% in Avignon, $11 \%$ at the Boston College and $0 \%$ in Oslo. On the opposite side, if asked about their favour for tenure, many people are in a 'dilemma' or 'in favour under specific conditions' but again the number of people 'definitely in favour' of tenure is the lowest ('Yes') in Twente: it's $29 \%$ in Twente, $44 \%$ at the Boston College, 53\% in Oslo, 63\% in Avignon. In Oslo and Twente there is strong evidence that older faculty favour tenure more than younger faculty (Currie et al., 2003).

Many statements from academics in Twente can give a flavour of what is going on there: “No, I don't think you should keep permanency. There are people who get older and slow down. I think you should be able as a University to say, 'Okay you did a great job, but now it's over' " (Junior, Female, Academic, Sciences) (Currie et al., 2003, p. 154); "You may offer permanency to your top professors and top academics, but it should be your own institutional choice to do so. In the current civil service system, you have a national rule about after working two years in a place, and then automatically have the right to permanency. That's bad. I recognize the need of the university to have some sort of mix of short contracts, longer contracts, and when you want to keep your quality academics, you have to offer open ended contracts and say, 'well you can stay here'. If not and they are good enough, then you feel the national and international competition, 'Okay, bye-bye, I have a better offer in Hamburg' "(Senior, Male, Academic, Sciences) (Currie et al., 2003, p. 152).

\section{The Idea of an Entrepreneurial University}

The University of Twente was officially created in 1961 by the Dutch government and the first 250 students were enrolled in 1964. It was located in Enschede, in the Netherlands region of Twente, in the province of Overijssel, close to the German border.

It's one of the newest of the 13 Dutch Universities and it's original name was Twente University of Technology, as from the beginning it was supposed to take a place between 
the previously established technological universities of Delft, founded in 1842, and Eindhoven, founded in 1956. The government, in fact, expected at that time shortages in engineers and scientists especially in chemical, mechanical and electrical engineering.

In the 1960s Twente, with its 600 thousand inhabitants, was a textile region and had a 'mono' industrial culture centred on textile and machinery. The strong and sudden decline of the textile industry, as firms fled to cheap-labour locations in other countries, was the main factor in the government's decision to establish the new university in Twente, and not in the other candidate locations, that were Arnhem, Deventer and Zwolle. Because of the decline in the textile industry Twente became a European Union (EU) Objective 2 region (it has now lost this status) ${ }^{2}$ and received money to develop the knowledge infrastructure (through the European Regional Development Fund, ERDF) and to develop its human resources (through the European Social Fund). The commitment of the local industries and cities in Twente and the availability of a superior and huge 'greenfield' location, very unusual for Europenan standard, finally settled the location matter of the 'campus university' in Enschede.

Very soon the University realized that it was located in a pastoral and green site, full of nice landscapes, lakes and forests but with no industrial structure to connect with, as the textile industry was disappearing, leaving empty textile mills as ghost-like and depressing memories of what had once been. Even from a geographic point of view Twente was at a disadvantage, as the most talented young people in the Netherlands prefer to study and live in the west, where most of the cultural, economic and political life goes on.

The number of students grew very slowly and was 2000 by 1970 and less than 4000 by 1978. Twente was very marginalized in the Dutch higher education system and had serious financial problems.

At the beginnings of the 1980s there were rumours that some faculties and even the University as a whole would have been closed down by the Dutch government.

At that same time a professor of mechanical engineering, Harry Van den Kroonenberg, a high profile public figure and strong-minded academic, with a reputation for leadership and imposing speeches, was appointed as Rector Magnificus. He was in office from 1979 to 1982 and again from 1985 to 1988 . He successfully delivered and ideologized the idea, at every level inside the organization, that the University of Twente should transform itself into 'the entrepreneurial university'. It was a real and hard campaign, with advertisings, speeches, public meetings and declarations to win hearts and minds inside the organization and to prepare the ground for what was going to happen. The mathematician Erik Bolle was appointed as administrative director.

Burton R. Clark (Clark, 1998), referring to universities, uses the term 'entrepreneurial' and 'innovative' as loosely synonymous, so implicitly adopting a schumpeterian view about entrepreneurship (Schumpeter, 1934). Finally, however, he chose the much more uncomfortable and debatable term 'entrepreneurial' over 'innovative', "because it points more powerfully to deliberate local effort, to actions that lead to change in organizational posture [...] a wilful effort in institution-building that requires much special activity and energy. Taking risks when initiating new practices whose outcome is in doubt is a major factor. An entrepreneurial university, on its own, actively seeks to innovate in how it goes about its business. [...] Entrepreneurial universities seek to become 'stand-up' universities that are significant actors on their own terms" (Clark, 1998, p. 4). 
According to Clark (1998), one needs five elements, as an irreducible minimum, in order to transform 'a traditional university' into an 'entrepreneurial university':

(1) a strengthened steering core: this factor concerns the internal organization of a university;

(2) an expanded developmental periphery: this factor concerns the way in which a university interacts with its environment, the type of organizational units and means, and programmes a university implements for the interactions;

(3) a diversified funding base: an entrepreneurial university should not be only dependent on government funds, but also use other types of funds, for example from industry or from the EU;

(4) a stimulated academic heartland: that is an excellent quality of research;

(5) an integrated entrepreneurial culture: an atmosphere of entrepreneurship and innovation should permeate every layer of the organization.

Of these five factors, the authors believe that the last one is the most vital and fragile, universities being 'heavy bottom' institutions in which opposition or passive attitude of personnel can paralyse whatever effort from whatever strengthened, competent and well funded steering core. The University of Twente, thanks to the credibility of its leadership and the 'ideologization' of an institutional idea, managed to create an integrated entrepreneurial culture, and only thanks to that base it could implement successful management practices in order to achieve its objectives of excellence and local economic relevance.

Twente's entrepreneurial attitude, at all levels, shows itself in many ways; here are some of the main ones:

- $1 / 3$ of the total financial support comes from the private sector and from competitive sources; testifying a diversified funding base;

- a real lump-sum budgetary system for faculties, departments and research centres;

- 437 spin-off companies from the University; 219 of which under a scheme designed by the University itself (Temporary Entrepreneurial Placements, TOP); out of the total number of companies, $68 \%$ are still in business offering employment opportunities to 3134 people; survival rate for TOP companies 75\%, for non-TOP companies $61 \%$ (Karnbeek, 2001, p. 5); testifying an expanded developmental periphery;

- it has been estimated that in $44 \%$ of the cases, spin-off companies are to a large or very large extent based on knowledge and contacts established in the University of Twente, which served as consultant and mentor during the start-up phase and often provided office spaces (Karnbeek, 2001, p. 7); testifying a stimulated academic heartland;

- a Business \& Science Park, occupying more than 40 hectares, home to some 195 companies and 4000 jobs;

- an effective business incubator, BTC-Twente Ltd, whose main shareholder is the University of Twente itself, which managed to fill in the gap between the Business \& Science Park and the newly born spin-off companies located inside the university;

- an active role in providing employment to students after graduation;

- consciousness that knowledge is generated by people and that establishing personal contacts between people from universities, industry and commerce is a precarious process which must be supported by the building up and maintaining of networks of 
personal relations, through the creation of programmes and schemes designed for this specific purpose.

In the following section about governance, it will be seen that a strengthened steering core is also provided, so that all the five elements identified by Clark (1998) are present at the University of Twente.

The lump-sum budgetary system, in particular, which was designed by the administrative director and mathematician Erik Bolle, also known in management studies as responsibility-centre budgeting, proved one of the most effective tools in educating an entrepreneurial spirit inside academia. It gave faculties and departments complete freedom and responsibility about how to spend the sum of money annually provided, producing a shocking shift towards 'accountability' and 'responsibility'.

Even if it's impossible to provide a recipe to create entrepreneurial culture inside universities, we provided evidence that it was possible in a marginalized university, located in a depressed area, without high-tech industries, without special financial resources and inside a traditionally centralized higher education system. Indeed, it's possible to argue that this marginalization was the main reason why the members of the organization felt they should have worked together towards change.

\section{A Governance Model for Entrepreneurship and Excellence}

The main issue of governance in higher education institution is "who are the people that are entitled to rule?"

It is commonly held, in a democratic view, that the people entitled to rule should be the people whose interests are affected. The point is that modern universities, having a key role in the transformation of industrial societies into the so called 'knowledege-based societies', have a multiplicity of functions and are actually affecting many different interests: students, academic and administrative personnel, regional governments, national government, local communities, industries and agencies (Lazzeretti \& Tavoletti, 2004).

This transformation became clear in the 1980s, just when Twente decided to evolve into 'the entrepreneurial university'. Untill the 1980s, universities were 'cultural institutions' whose main functions were "embodying and fostering the cultural heritage of a country" (Braun \& Merrien, 1999, p. 12). From around 1970 on, society was also asking the universities to leave their ivory tower and become relevant to society. This was part of the critical movements, but also visible in governance, for example through democratization of universities, including having non-academics as member of the university council. What was new in the 1980s was the emphasis on serving economic and policy goals, rather than general relevance. Starting from the 1980s, society began to ask much more and to consider universities as public service institutions. Everywhere political decision-makers began to demand that quasi-public institutions such as universities presented useful and applicable results linked to concrete social, political and economic goals and submitted to an assessment procedure regarding their efficiency in terms of input and output. "The lack of transparency concerning the fruitfulness of scientific activities, the shutting-off of university life from social and economic demands [...] were often criticised. The protective aura of a cultural institution begins to pale, forcing the universities to base their legitimacy on new foundations" (Braun \& Merrien, 1999, p. 14). 
As a consequence, the issue of identifying the different 'stakeholders' for a university and to design effective governance, was a crucial task.

According to the famous and cited Clark's 'triangle' (Clark, 1983, p. 143), advanced industrial countries have developed different forms of higher education coordination which are located between three axes: a more market-like coordination (as it happens in the US), a more state-induced coordination (like in Sweden), and a form of coordination which is based on the rule of the academic oligarchy (like in Italy) (Braun \& Merrien, 1999).

Many other attempts to systematize governance systems were followed in higher education but for Twente, the most explicative one seems to be that one from Van Vught (1989), who reduces the Clark' triangle into two models:

(1) a state control model: typical of many European countries, with strong authority of both academic oligarchy and state bureaucracy and a weak management inside the university; the government intrudes into higher education by means of strict and detailed regulation and strict control;

(2) a state supervising model: typical of the Anglo-Saxon tradition, where state bureaucracy is very weak, and the power is divided between the academic oligarchy and the internal management.

In the Netherlands there are 13 universities and till the beginning of the 1970s in all of them there was a strict separation between management of academic affairs (the senate, representing the academic oligarchy) and non-academic affairs (the college van curatoren or 'board of curators', representing the state bureaucracy).

In 1970 the Act of University Governance abolished both the senate and the college van curatoren.

They were replaced by: (1) 'university council'; (2) a 'chief executive board'; (3) a 'board of deans'. The 'university council', representing academics (one third), nonacademics personnel and general public from outside the university (one third) and students (one third), had a 'legislative function' and approved the budget. The 'chief executive board' (college van bestuur) consisted of five members, including the rector magnificus: the national government appointed the rector and two other members (choosing among the nominations submitted by the 'university council' and the 'board of deans'), the 'university council' elected the other two members. The 'chief executive board' had all the powers previously held by the college van curatoren. The 'board of deans' had mainly advisory powers regarding teaching and research.

In 1997 the Act Modernizing University's Governance Structures definitely shifted the system from a state control model to a state supervising model in which "a new hierarchical management system based on appointments replaced the old, democratic system, inclusive of all interested groups based on elections" (Currie et al., 2003, p. 94). The new system consisted of: (1) the 'university council' with an advisory function (it no longer approved the budget or had legislative powers); (2) a 'supervisory body' (raad van toezicht), consisting of five members appointed by the minister and accountable to him, responsible for the strategic management and the planning of the institution; (3) an 'executive board', with much more powers than the previous college van bestuur and consisting of a maximum of three people, including the rector, all of them appointed by the 'supervisory body'. 
The new Act gave much more power to faculties and deans (these ones appointed by the 'executive board' who can choose people coming from outside the university) and favoured single-headed authorities and managerialism, meaning strengthened executive leadership, and so a strengthened steering core. The Act also shortened the "chain of command' eliminating many 'departments' and leaving just advisory powers to faculty councils (half of the faculty council members, whose size varied from three to over 20 , must be students).

It is important to add that in Twente it has always been difficult to find people who want to be elected in representative bodies so that elections proved to be a difficult job and the appointment system was quite a relief for everyone.

When Van den Kroonenberg was appointed rector, and one of the five members the 'chief executive board' (college van bestuur), in 1979, he had not just the leadership but also the executive powers to establish an office (Transferpunt) with two main objectives: (1) looking for additional income to deal with reducing sources from the government; (2) helping the declining local economy, providing assistance to students who wanted to start their own business. In 1984 this led to the establishments of a very successful programme, called the TOP programme.

The main objective of TOP was to encourage and help graduates from the university to start their own knowledge-based company. What a graduate needed was a credible business plan and a business idea matching the interests of staff members in one of the research groups of the university. During the first year the knowledge-based company could stay inside the university (taking free advantage of office-space, communications, laboratory facilities, courses about entrepreneurship and a small personal loan). In the following 2 years the company was supposed to move out of the university and into the business incubator, just on the border of the campus (BTC), where it was supposed to pay for the provided services (the main stakeholder of BTC is the University of Twente itself). When the company was too big for the business incubator it was supposed to establish itself into the 'Business \& Science Park' surrounding the campus. As has already been seen, 219 companies were born under the TOP programme and $75 \%$ of them are still alive.

Very soon the University of Twente began to consider itself a 'public service institution' for local development more than a 'cultural institution' and coherently began to monitor quality and the efficiency and effectiveness of its mission. The mission was embodied at every level of the institution and personnel were active and cooperative.

The different accountability mechanisms were well accepted by personnel, because they were perceived as tools to achieve that mission, and the lump-sump budgeting system (which makes faculties pay the central administration for the use of computing facilities, lecture halls, libraries and office spaces) made everyone aware that "there is not such a thing as a free lunch".

Soon the University made internal funding for research as competitive as the funding from outside sources and in the late 1990s it even selected excellence centres for extra money. The achievements in 'Strategic Science' (Rip, 2002a, 2002b) were high quality and in fields such as membrane science and technology, biomedical materials and technologies, nanotechnology and ICT. The University of Twente has formally selected five areas in which to strive for excellence in the future. The areas are: ICT; microsystems technology; biomedical technology; chemical process engineering and governance.

Following Arie Rip (2002a) 'Strategic Science' is defined as a 'regime' of more or less stabilized rules of how to proceed, in doing science as well as in organizing it and 
legitimating it. Under this regime the distance between scientific research and eventual applications disappears and scientists have internalized the social pressure for relevance of research: the new scientific establishment promises to contribute to wealth creation and sustainability (and working toward it) and forges new alliances with policy-makers and social actors on this basis. Under this regime not every research programme ends in an actual prototype or commercial product, of course, but horizontal mobility of scientists and lateral combinations benefit industrial innovation. This was often the case in Twente, for example when physicists, chemists and electronic engineers worked together in a research programme to find a micro-optics alternative to micro-electronics. The research programme was not successful but the "various participants were reasonably successful in taking up other, but related research and linking it with national research programmes and relevant industrial actors" (Rip, 2002b, p. 126).

\section{An 'Embedded University'}

As underlined by Philip Cooke "probably one reason greater pressure is now put on universities to take the lead in regional economic development, apart from the obvious one that they are heavily implicated as sources of potential knowledge commercialisation, is that they are among the few organizations in any given region with legitimate authority to speak knowledgeably on science, technology and, it is hence believed, innovation and the policy to support it" (Cooke, 2003, p. 50). As a consequence universities are corner stones of the governance structure of 'knowledge economies' or, even more often, local systems and regions whose ambition is to become 'knowledge economies'.

In 'Knowledge Economies', Philip Cooke (2003) draws the conclusion that 'cut-throat' competition works against competitive advantage (let alone cooperative advantage), while vertical interaction in the governance sphere and horizontal interaction and regional partnership for collective learning produce promising results for policies seeking to promote knowledge economies. It is a conclusion not different from the one he theorized for traditional economies in 'The Associational Economy' (Cooke \& Morgan, 1998) but it is much more detailed on the policy level, with the new concepts of multi-level governance and cultural embeddedness as an evolutionary process. The authors believe that the model developed by Philip Cooke applies well to the region of Twente and its University, because the University had a leading role in the creation of a knowledge economy, through an evolutionary process in which regional partnerships for collective learning and vertical interaction in a 'multi-level governance framework' were both promoted (the EU, the national government, the regional and local government, all played a key role).

In 1997 the University of Twente presented a quantitative study concerning its effects on the region of Twente and the province of Overijssel, ${ }^{3}$ based on the model developed by Florax in 1987 (Florax, 1987). It concluded that the University of Twente had substantial effects on the region and classified them into several categories: demography, politics, economy, infrastructure, culture, attraction, education, social effects (Table 1).

In 1992 Florax had already published an impressive and methodologically well founded empirical research. He adopted an input-output technique to measure the 'expenditure impact' of the University of Twente on regional income and employment in the province of Overijssel in 1990 (Florax, 1992). He concluded that in 1990 income and employment effect, produced by university's expenditure, let alone every kind of 'knowledge impact', accounted for approximately $1.3 \%$ of total income and employment in Overijssel. He also 
Table 1. Facts and figures about the University of Twente for 2000-2001

\begin{tabular}{lr}
\hline Number of (Masters) students & 5884 \\
Number of International Masters students (post graduate) & 59 \\
Number of Ph.D. theses & 96 \\
Number of publications & 640 \\
Number of patents & 31 \\
Number of scientific personnel & 1319 \\
Number of non-scientific personnel & 1337 \\
Financial affairs & \\
Contributions (government and other) + fees & 128.4 million euro \\
Second flow of money (national funds) & 12.6 million euro \\
Second flow of money (international funds) & 4.2 million euro \\
Third flow of funds & 23.7 million euro \\
Sundries & 16.1 million euro \\
\hline
\end{tabular}

Source: Van der Sijde et al., 2002a, p. 171 (ours is the changeover from florins to euros).

concluded that in Twente and generally in peripheral regions "the geographical proximity to academic knowledge production accelerates the process of economic obsolescence, which in turn enhances the level of investments" (Florax, 1992, p. 239).

Even if, at a first glance, it may be argued that the benefits for the region of Twente $(600,000$ inhabitants) and the province of Overijssel are not equally distributed and mostly concentrated within a range of $20 \mathrm{~km}$ around the University (in the 'Business \& Science Park, Enschede'), where the concentration of spin-off companies is more visible and higher, an investigation conducted on a sample of 189 spin-off companies showed that more than a half of them (72.4\%) located head offices elsewhere in the region and in the country and only $27.6 \%$ located in the direct vicinity of the University (in the university campus and in the 'Business \& Science Park, Enschede') (Table 2).

Table 2. Geographical location of companies' head offices

\begin{tabular}{|c|c|c|c|c|c|c|}
\hline & \multicolumn{2}{|c|}{ Total } & \multicolumn{2}{|c|}{ TOP } & \multicolumn{2}{|c|}{ Other } \\
\hline & $n$ & $\%$ & $n$ & $\%$ & $n$ & $\%$ \\
\hline University of Twente Campus & 9 & 4.8 & 4 & 3.4 & 5 & 6.8 \\
\hline Enschede Business \& Science Park & 43 & 22.8 & 23 & 19.8 & 20 & 27.4 \\
\hline Enschede/Hengelo & 72 & 38.1 & 46 & 39.7 & 26 & 35.6 \\
\hline Elsewhere in Twente & 24 & 12.7 & 18 & 15.5 & 6 & 8.2 \\
\hline Elsewhere in Overijssel & 9 & 4.8 & 2 & 1.7 & 7 & 9.6 \\
\hline Groningen & 2 & 1.1 & 1 & 0.9 & 1 & 1.4 \\
\hline Friesland & 3 & 1.6 & 3 & 2.6 & 0 & 0.0 \\
\hline Drenthe & 1 & 0.5 & 0 & 0.0 & 1 & 1.4 \\
\hline Gelderland & 10 & 5.3 & 5 & 4.3 & 5 & 6.8 \\
\hline Flevoland & 1 & 0.5 & 1 & 0.9 & 0 & 0.0 \\
\hline Noord-Holland & 4 & 2.1 & 4 & 3.4 & 0 & 0.0 \\
\hline Zuid-Holland & 7 & 3.7 & 5 & 4.3 & 2 & 2.7 \\
\hline Brabant & 2 & 1.1 & 2 & 1.7 & 0 & 0.0 \\
\hline Limburg & 1 & 0.5 & 1 & 0.9 & 0 & 0.0 \\
\hline Zeeland & 1 & 0.5 & 1 & 0.9 & 0 & 0.0 \\
\hline Total & 189 & 100.0 & 116 & 100.0 & 73 & 100.0 \\
\hline
\end{tabular}

Source: Karnebeek, 2001, p. 27. 
Table 3. Geographical location of companies' head offices, aggregated by regions

\begin{tabular}{|c|c|c|c|c|c|c|}
\hline & \multicolumn{2}{|c|}{ Total } & \multicolumn{2}{|c|}{ TOP } & \multicolumn{2}{|c|}{ Other } \\
\hline & $n$ & $\%$ & $n$ & $\%$ & $n$ & $\%$ \\
\hline Twente & 148 & 78.4 & 91 & 78.4 & 57 & 78.0 \\
\hline Elsewhere in the province of Overijssel & 9 & 4.8 & 2 & 1.7 & 7 & 9.6 \\
\hline Elsewhere in the Netherlands & 32 & 16.8 & 23 & 19.9 & 9 & 12.4 \\
\hline Total & 189 & 100.0 & 116 & 100.0 & 73 & 100.0 \\
\hline
\end{tabular}

Source: Karnebeek, 2001, p. 27.

The data about the distribution of TOP companies and non-TOP companies clearly show that Twente is not just a 'science park phenomena' but a 'regional development phenomena' where policy (e.g. the TOP programme) played a major role. Table 3 shows the same data in a less detailed version.

The TOP programme which had a very important role in the development of spin-offs companies and was established to encourage graduates of the university to start their own knowledge-based business, is the result of a cooperation among the University of Twente, the national government, the regional government and the EU, through a vertical interaction in a 'multi-level governance framework'. It started as a 'bottom-up' programme, from a 'leading university', when Professor Van den Kroonenberg decided to support his own students with his own money and, the programme being very successful, received financial support and attention from the Dutch Ministry of Economic Affairs and later from the European Social Fund; regional authorities and mentors from industry supported the programme from the very beginning. An extrapolation of 297 companies out of 437 that have sprung from the University of Twente (68\% of which are still in business) shows that they provide 3134 employment positions in high-tech industries and with increasing trends in the number of jobs per company (Table 4).

The most important fields of study that the companies surveyed consider crucial to their activities are mechanical engineering (37\%), ICT (36\%), microsystems technology (22\%), chemical technology (12\%), biomedical technology (6\%) and management studies (45\%). Most of them had important contact with the University of Twente during the start-up phase (Table 5).

All the University of Twente faculties or departments had contact with spin-off companies during the start-up phase (the most active was 'mechanical engineering' who had contact in $18.9 \%$ of the cases; the less active was 'applied mathematics' with $1.6 \%$; 'philosophy and social sciences' scored a surprising 3.3\% the same percentage as the

Table 4. Number of spin-offs, total employment and average number of jobs per company

\begin{tabular}{lcccccc}
\hline & 2000 & 1997 & 1993 & 1990 & 1984 & 1980 \\
\hline Employment positions & 3,134 & 1,836 & 895 & 1,094 & 295 & 141 \\
Number of companies & 297 & 211 & 179 & 144 & 82 & 38 \\
Number of jobs per company & 10.6 & 8.7 & 5.0 & 7.6 & 3.6 & 3.7 \\
\hline
\end{tabular}

Source: Karnebeek, 2001, p. 23. 
Table 5. Number and types of contact between University of Twente (UT) and spin-off companies in the start-up phase

\begin{tabular}{lccc}
\hline & Total $(\%)$ & TOP $(\%)$ & Non-TOP $(\%)$ \\
\hline Consultative/mentoring function & 46.8 & 61.4 & 24.3 \\
Use of UT facilities & 20.2 & 22.8 & 16.2 \\
Use of UT trainees and/or students & 11.7 & 14.9 & 6.8 \\
Occasional client referral from the UT & 11.7 & 13.2 & 9.5 \\
Completion of assignments for the UT & 10.1 & 12.3 & 6.8 \\
Solving specific technological problems & 6.9 & 9.6 & 2.7 \\
We occasionally provide visiting lectures to the UT & 4.3 & 5.3 & 2.7 \\
We outsource work for the UT & 3.2 & 5.3 & 0 \\
We occasionally refers clients to the UT & 2.1 & 2.6 & 1.4 \\
The UT and us engage in joint promotion campaigns & 1.6 & 0 & 4.1 \\
Use of UT trainee research assistants & 0.5 & 0.9 & 0 \\
No contact whatsoever with UT & 17.1 & 7.9 & 31.1 \\
Other & 3.7 & 0 & 9.5 \\
Do not know & 3.7 & 2.6 & 5.4 \\
\hline
\end{tabular}

Source: Karnebeek, 2001, p. 40.

'business school') and in many cases these contacts were maintained well beyond the startup phase (Table 6) and with a high degree of satisfaction with the contact reported by the companies (Table 7).

It can be concluded that the University of Twente played a leading role in the development of a 'knowledge economy' in the region of Twente, through regional partnerships for collective learning and vertical interaction in a 'multi-level governance' framework (Cooke, 2003). It successfully produced 'knowledge' by means of actions and interactions with local agents. The authors believe that the University of Twente involved itself in the production of a kind of 'knowledge' strictly linked to application and action in the

Table 6. Number and types of contact between University of Twente (UT) and spin-off companies after the start-up phase

\begin{tabular}{lccc}
\hline & Total $(\%)$ & TOP $(\%)$ & Non-TOP (\%) \\
\hline Consultative/mentoring function & 30.7 & 37.1 & 20.5 \\
Use of UT facilities & 14.8 & 16.4 & 12.3 \\
Use of UT trainees and/or students & 14.3 & 15.5 & 12.3 \\
Occasional client referral from the UT & 9.0 & 10.3 & 6.8 \\
Completion of assignments for the UT & 7.9 & 7.8 & 8.2 \\
Solving specific technological problems & 4.8 & 5.2 & 4.1 \\
We occasionally provide visiting lectures to the UT & 4.2 & 4.3 & 4.1 \\
We outsource work for the UT & 3.7 & 5.2 & 1.4 \\
We occasionally refers clients to the UT & 3.7 & 4.3 & 2.7 \\
The UT and us engage in joint promotion campaigns & 3.2 & 0 & 8.2 \\
Use of UT trainee research assistants & 1.1 & 1.7 & 0 \\
No contact whatsoever with UT & 35.4 & 31.0 & 42.5 \\
Other & 2.6 & 2.6 & 2.7 \\
Do not know & 0.5 & 0 & 1.4 \\
\hline
\end{tabular}

Source: Karnebeek, 2001, p. 47. 
Table 7. Satisfaction with post start-up phase contacts

\begin{tabular}{|c|c|c|c|c|c|c|}
\hline \multirow[b]{2}{*}{ Satisfaction with current contact } & \multicolumn{2}{|c|}{ Total } & \multicolumn{2}{|c|}{ TOP } & \multicolumn{2}{|c|}{ Other } \\
\hline & $n$ & $\%$ & $n$ & $\%$ & $n$ & $\%$ \\
\hline Highly satisfied & 43 & 35.2 & 22 & 27.5 & 21 & 50.0 \\
\hline Satisfied & 75 & 61.5 & 55 & 68.8 & 20 & 47.6 \\
\hline Dissatisfied & 3 & 2.5 & 2 & 2.5 & 1 & 2.3 \\
\hline Highly dissatisfied & 1 & 0.8 & 1 & 1.3 & 0 & 0.0 \\
\hline Total & 122 & 100.0 & 80 & 100.0 & 42 & 100.0 \\
\hline
\end{tabular}

Source: Karnebeek, 2001, p. 47.

surrounding community and very similar to a definition of 'knowledge' as ability to produce an effective action in a consensual domain, nurtured and sustained through continuous social interactions (Tavoletti, 2004). A strong entrepreneurial vision was seen, and an integrated entrepreneurial culture was not just a crucial point but the starting point and even the leading cause of the entire process.

\section{Conclusion}

The University of Twente developed a strong entrepreneurial vision inside its own organization, thanks to the will and ability of its leadership, who was able to create a favourable climate and to design an effective infrastructure for successful academic spin-off companies. The new-born companies allowed the university to be engaged in the production of what is defined as 'social knowledge', giving the institution the opportunity for effective interactions with the local economy and embedding the University in the region. Governance reforms at the national level, that the higher education literature refers to as the "new managerialism governance model' (Braun \& Merrien, 1999), helped, but they followed events and seem to be the consolidation of an already increasingly strengthened steering core.

For a long time the University of Twente has been a 'regional booster' for the development of a regional 'knowledge economy', starting from a previously depressed local economy, achieving a relevant international position in the world of Strategic Science and with all of its graduates finding good jobs. Whatever priorities are to be assigned to a university, such as achievements of research, graduates employment or contribution to local and regional development, the University of Twente, starting from a very unfavourable position, has reached high quality standards.

But what is the secret of this success and is there any lessons to be learnt from this single case study?

The general conclusion to be drawn from this single case study is that, citing Arie Rip, "The two sides of Strategic Sciences, relevance (local) and excellence (global), can actually be pursued at the same time. Mode 2 of knowledge production, as Gibbons et al. (1994), would call it, is finding its institutional forms" (Rip, 2002b, p. 128). Through this case study the opportunity to verify that local economic relevance for universities and their international excellence are not incompatible objectives because they were not in Twente and under very unfavourable conditions was possible. 
The emergence of knowledge production Mode 2 makes the traditional division of labour between fundamental and applied research irrelevant in many cases, and with it the functional distinctions between universities' labs and industrial research. In this new situation it is much easier for universities to produce a kind of knowledge both relevant for the local economy and for the global search of new knowledge: "post-modern universities will include overlaps and alliances with Centres (of excellence and relevance), public laboratories of various kinds (themselves on the move!) and various private organisations managing and performing research. The boundaries between the university and the outside world are porous, and such 'porosity' is sought explicitly" (Rip, 2002a, p. 6).

It is obvious that Twente's experience cannot be duplicated everywhere, cultural embeddedness being an evolutionary process (Cooke, 2003), but nonetheless it is a relevant point to see that it was possible there, under very unfavourable circumstances, through the ability of a newly born university to produce an 'effective action' (Tavoletti, 2004) in the surrounding community, creating its own responsive agents for future 'knowledge interactions'.

The University of Twente is mainly a technical one, with a strong hard science core, where applied social sciences seem to play a less relevant role. In that sense it cannot be suggested that its experience could be immediately applied to universities focused on humanities. Nonetheless, the University of Twente's experience shows to other numerous technical and peripheral European universities that are currently 'dwelling on their misfortunes', that being peripheral and with no advanced economy nearby is not a good excuse to justify inaction, no engagement for local economic development or poor quality of research. At least in technical universities with applied social sciences departments, engagement for local economic development and international excellence can be pursued jointly, even in peripheral areas starting from the unfavourable conditions described for the case of the University of Twente.

\section{Acknowledgements}

This work would have been impossible without Professor Dr Arie Rip, director of the Centre for Studies of Science, Technology and Society at the University of Twente. He welcomed one of the authors in to his Centre and provided invaluable assistance and advise for the work. The authors would also like to thank all the people from the Centre for Higher Education Policy Studies (CHEPS) at the University of Twente, who were very welcoming, joined in very productive discussions and allowed the use of their excellent library, from which this work draws heavily. The authors are grateful to all of those who have discussed this paper with them, and from whom they have learnt much. In that sense a very special thank you to the colleague and friend Robbin A. te Velde. Finally, thanks also to the two anonymous referees (whoever and wherever you are) for their comments.

\section{Notes}

1. An early version of the paper was presented at the 6th 'Toulon Verona' Conference on Quality in Higher Education, Health Care, Local Government, Oviedo, Principado de Asturias, Spain, 10-12 September 2003. 
2. Up till recently (2000) the region of Twente was an Objective 2 region and at this moment Twente is in the phasing-out programme.

3. The study is edited by the University of Twente itself and is in Dutch: University of Twente (1997), The University of Twente as the motor of the economy of Twente; a study of the economic effects of the University of Twente in the region of Twente, Internal report from the University of Twente: cited in Van Alsté and Van der Sijde (1998).

\section{References}

Birnbaum, R. (2001) Management Fads in Higher Education (San Fransisco, CA: Jossey Bass).

Braun, D. \& Merrien, F. (1999) Towards a New Model of Governance for Universities? A Comparative View (London: Jessica Kingsley Publishers).

Clark, B. (1983) The Higher Education System. Academic Organizations in Cross-national Perspective (Berkley, CA: University of California Press).

Clark, B. (1998) Creating Entrepreneurial Universities, Organizational Pathways of Transformation (Oxford: Elsevier Science for the International Universities Association Press Pergamon).

Cooke, P. (2003) Knowledge Economies (London: Routledge).

Cooke, P. \& Morgan, K. (1999) The Associational Economy (Oxford: Oxford University Press).

Currie, J., De Angelis, R., de Boer, H., Huisman, J. \& Lacotte, C. (2003) Globalizing Practices and University Responses (Boston, MA: Praeger Publishers).

Etzkowitz, H. \& Leydesdorff, L. (1997) Universities and the Global Knowledge Economy, a Triple Helix of University-Industry-Government Relations (London: Pinter).

Florax, R. (1987) The Regional Economic Role of Universities; The Dark Side of Universities (Enschede: Centre for Higher Education Policy Studies).

Florax, R. (1992) The University: A Regional Booster? Economic Impacts of Academic Knowledge Infrastructure (Aldershot: Avebury).

Gibbons, M., Nowtny, H. \& Scott, P. (2001) Re-Thinking Science, Knowledge and the Public in an Age of Uncertainty (Cambridge: Polity Press).

Groen, A. J. \& Van der Sijde P. C. (2002) Universiy-Industry Interaction, Examples and Best Practice in the European Union (Enchede: Twente University Press).

ISTAT (2001) Unemployment Rates for Year 2001, Available at www.istat.it.

Karnbeek, A. J. (2001) Spin-offs and the University of Twente (Enschede: Twente University Press).

Lazzeretti, L. \& Tavoletti, E. (2004) Governance shifts in higher education: a cross national comparison, paper presented at the Workshop on the Process of Reform of the University Across Europe, Siena, Italy, 24-26 May, organized by the European Institute for Advanced Studies in Management (EIASM), proceedings; submitted to the Journal of Governance and Management.

Neave, G. (1994) The politics of quality: development in higher education in Western Europe 1992-1994, European Journal of Education, 29(2), pp. 115-134.

OECD (1999) The Response of Higher Education Institutions to Regional Needs (Paris: OECD).

OECD (2002) Education at a Glance (Paris: OECD).

Rip, A. (2002a) Strategic research, post modern universities and research training, paper presented at the International Conference on Science, Training and Career: Changing Modes of Knowledge Production and Labour Markets, University of Twente, 21-22 October.

Rip, A. (2002b) Regional innovation systems and the advent of strategic science, Journal of Technology Transfer, 27 , pp. $123-131$.

Rip, A. (2003) Writing about the transformation of science, Meta Science, forthcoming.

Romzek, B. S. (2000) Dynamics of public sector accountability in an area of reform, International Review of Administrative Sciences, 66(1), pp. 21-24.

Rutten, R., Boekema, F. \& Kuijpers E. (2003) Economic Geography of Higher Education, Knowledge Infrastructure and Learning Regions (London: Routledge).

Schumpeter, J. (1934) The Theory of Economic Development (Cambridge, MA: Harvard University Press).

Tavoletti, E. (2004) Higher education and high intellectual unemployment: does education matter? An interpretation and some critical perspectives, in: P. Cooke \& A. Piccaluga (Eds) Regional Economies as Knowledge Laboratories (Northampton: Edward Elgar Publishers).

Trow, M. (1996) Trust, markets and accountability in higher education: a comparative perspective, Higher Education Policy, 9(4), pp. 309-324. 
Van Alsté, J. A. \& Van der Sijde, P. C. (1998) The Role of the University in Regional Development (Enschede: Twente University Press).

Van der Sijde, P. C. \& Ridder A. (1999) Commercialising Knowledge, Examples of Entrepreneurship at the University of Twente (Enschede: Twente University Press).

Van der Sijde, P. C. \& Ridder A. (2000) Support of university spin-off companies, Entrepreneurship and Innovation, February, pp. 13-21.

Van der Sijde, P. C. \& Van Driem, G. A. (1999) Incubation infrastructure for knowledge-intensive companies around the University of Twente, Industry and Higher Education, August, pp. 243-247.

Van der Sijde, P. C. \& Van Tilburg, J. (1998) Creating a climate for university spin-offs, Entrepreneurship and Innovation, October, pp. 297-302.

Van der Sijde, P. C., Ridder, A., Van Benthem, J. \& Groen, A. (2002a) Entrepreneurship and entrepreneurship stimulation at the University of Twente, in: P. C. Van der Sijde, A. Ridder, J. M. Gòmez, J. T. Pastor, D. Galiana \& I. Mira (Eds) Infrastructure for Academic Spin-off Companies, pp. 167-193 (Luxembourg: European Commission, Enterprise Directorate-General Innovation and SMEs).

Van der Sijde, P. C., Vogelaar, G., Hoogeveen, A., Ligtenberg, H. \& Van Velzen, M. (2002b) Attracting high tech region, the case of the University of Twente and its region, Industry and Higher Education, 16(2), pp. $97-104$

Van Vught, F. A. (1989) Governmental Strategies and Innovation in Higher Education (London: Jessica Kingsley Publishers).

Weerte de, E. \& Van Vught Tijsen, L. (1999) Academic staff between threat and opportunity: Changing employment and conditions of service, in: B. Jongbloed, P. Maasen \& G. Neave (Eds) From the Eye of the Storm: Higher Education's Changing Institution, pp. 39-63 (Dordrecht: Kluwer Academic Publisher).

Wolf, A. (2002) Does Education Matter? Myths about Education and Economic Growth (London: Penguin Books).

Yin, R. (1989) Case Study Research. Design and Methods (London: Sage Publications). 
Copyright of European Planning Studies is the property of Carfax Publishing Company and its content may not be copied or emailed to multiple sites or posted to a listserv without the copyright holder's express written permission. However, users may print, download, or email articles for individual use. 